\title{
ファジィ理論を用いた道路交通流解析* \\ Transport Network Analysis using Fuzzy Set Theory
}

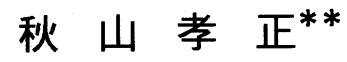 \\ By Takamasa Akiyama
}

\section{1.はじめに}

計算機を用いて人間の思考を表現しょうとする試 みは、計算機が実用化されて以来研究されている課 題である。土木工学分野でも人工知能 (A I )、ファ ジィ理論、ニューラルネットワークなどの計算機工 学の成果を利用して、応用的意義を見いだす努力が 行われている。ファジィ理論(Fuzzy Set Theory)は、 1965年のProf.L.A.Z adehによる提唱から約 30 年を 経て、近年わが国を中心に、理論的研究や多くの分 野で実用的応用が行われている1,2)。

土木計画の分野においても、一般の応用分野にお いてもファジィ理論は確率論と対置して議論される ことが多かった。しかし両者は、理論的にも実用的 にも相反するものではなく、強いていえば相補的な 関係にある。一部の分野では歴史的に研究者が確率 手法に馿染んでいること、またファジィ理論で行わ れる理論展開が確率論のそれに類似している部分が あることから「確率とファジィはどちらが正当 か?」という問題提起も少なくない。

しかしながら、両者に相対する概念があるわけで もなく、また一方が他方を代替するわけでもないか ら、実際にはこれらの優劣を述べることに意味はな い。また現実にファジィ理論が産業界での実用的側 面で多くの成果を挙げていることからも、これらの

*Key Words ファジイ推論、認知所要時間、交通
現象解析
* * 工博 京都大学講 工師 工学部交通土木工学教室
( ₹606 京都市左京区吉田本町)

応用される側面が異なりファジィ理論が有効に機能 する分野があることを知ることができる。

土木計画・交通計画の分野では、たとえば確率論 的な非集計行動モデルを基本に用いる確率均衡配分 法が提案されている ${ }^{3}$ 。このような分析手順と同様 に、ファジィ理論をベースとした交通行動現象の分 析から交通流解析問題へと検討を行うことができる。 これは交通現象分析のなかでも現象記述型の経路選 択モデルと交通量推計上での交通配分問題への応用 に対応している。

本研究ではまず、実用的な交通量推計として転換 率を用いた交通量配分について検討する。つまり都 市高速道路と一般道路で構成される都市道路網に対 する実用的な交通量配分時に利用できる高速道路転 換率推計モデルの作成である。

つぎに広域的な道路網上の交通量分布を知るため の交通量配分手法について考察する。ここでは、所 要時間認知のファジィ性を中心に議論する。特にラ ンダム数とファジィ数の概念を整理するとともに、 ファジィ所要時間を用いた交通量配分法に関連する 事項を検討する。この中心的方法はファジィ数の演 算とその応用である。そして、以上の検討から最終 的に、ファジィ理論の対象とする問題を明確にする とともに具体的な問題解決方法について述べる。

\section{2. ファジィ推論による道路利用率推計}

\section{1 ファジィ推論モテル}

ファジィ推論は、各分野で害用的に用いられてい 
る方法のなかで、最も多くの応用例が見られる方法 である。この「推論」の基本概念は、エキスパート システムで通常用いられるIF/THEN型のモデルを人 間の持つ言語表現に適する形で修正を加えるもので ある。したがって、条件命題と帰結命題をファジィ 集合を用いて記述したものである。詳細な演算方法 については、昨今極めて多数の書物が刊行されてい

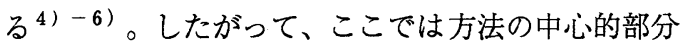
を簡単に記すことにする。

我々の日常的な推論の例としてつぎのようなもの がある。

規則：もし道路が混雑していれば 所要時間は大きい

事実 : この道路は少し混雑している。

結論 : この道路では所要時間はやや大きい。

これを一般的な推論形式として示すと、

規則 : If $x$ is $A$ then $y$ is $B$

$$
\text { 事実: } \quad x \text { is } A^{\prime}
$$

結論： $\quad y$ is $B^{\prime}$

ここで、A、A'、B、B'はファジイ概念であ り、Aと $A^{\prime}$ は全体集合 $\mathrm{X} 、 \mathrm{~B}$ と $\mathrm{B}$ 'は全体集合 $\mathrm{Y}$ におけるファジィ集合で表される。このようなファ ジィ命題を持つような推論をファジィ推論(F uz zy Reasoning) という。ファジィ推論は、通常の記号推 論と異なり、AとA'が必ずしも一致しなくてもよ い点に特徵がある ${ }^{7) 。}$

つまりファジィ推論は、「IF〜 THEN $\cdots$ …形式の 推論を利用しながらクリスプ推論をファジィ理論を 用いて一般的に拡張するものである。

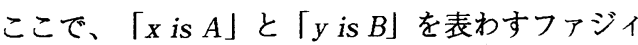
集合 $\mathrm{A}, \mathrm{B}$ がそれぞれメンバシップ関数 $\mu_{A}(x), \mu_{B}(y)$ で 表されるとする。このとき「If $\mathrm{x}$ is $\mathrm{A}$ then $\mathrm{y}$ is $\mathrm{B}$ 」 の推論を表すファジィ関係Rは、 $x$ と $y$ から決定され るメンバシップ関数 $\mu_{R}(x, y)$ で表される。このときファ ジィ推論モデルで最も基本的な形である「論理積」 （min）を用いると $\mu_{R}(x, y)$ を定義できる。すなわち、

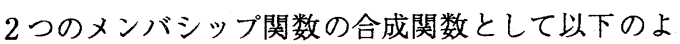
うに表わされる。
$\mu_{R}(x, y)=\mu_{A}(x) \wedge \mu_{B}(y)$

このとき、さきの推論ルール「If $\mathrm{x}$ is $\mathrm{A}$ then $\mathrm{y}$ is $\mathrm{B}$ 」は、集合 $\mathrm{A}$ と関係 $\mathrm{R}$ 用いて集合 $\mathrm{B}$ を求めるため の以下の計算を行うことに等しい。

$$
\mu_{B}(y)=\int \sup \left[\mu_{A}(x) \wedge \mu_{R}(x, y)\right] / y
$$

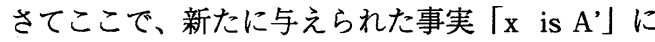
対して、ファジィ集合 $\mathrm{A}^{\prime}\left(\right.$ メンバシップ関数 $\mu_{\mathrm{A}^{\prime}}(\mathrm{x})$ ) を与えると推論結果は次のように得られる。

$\mu_{B},(y)=\int \sup \left[\mu_{A^{\prime}}(x) \wedge \mu_{R}(x, y)\right] / y$

つまり、推論を表現するため、ファジィ集合 A $\mathrm{B}$ 間のファジィ関係 $\mathrm{R}$ をメンバシップ関数 $\mu_{\mathrm{R}}(\mathrm{x}, \mathrm{y})$ で 表わす。集合 $\mathrm{A}$ と類似した集合 $\mathrm{A}^{\prime}$ に対して、一連 の演算を行い集合 $\mathrm{B}$ 'を示すメンバシップ関数 $\mu_{\mathrm{B}}$ (y)を求めるものである。この手順は図一1のように 書くことができ、ファジィ推論モデルは、本図に示 す各手順を定式化することによってモデルが形成さ れる8),9)。

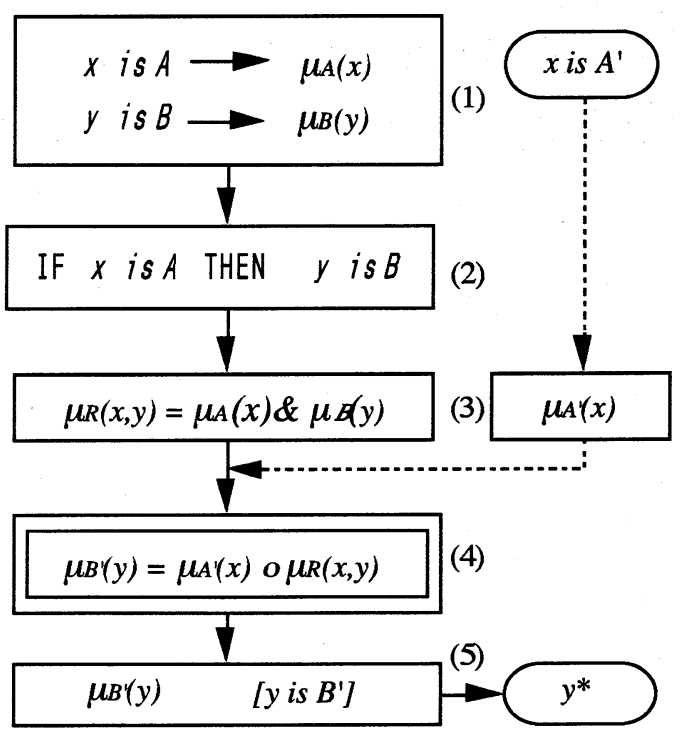

図一 1 ファジィ推論の演算手順 
すなわち（1）ファジィ数の決定 $\left(\mu_{\mathrm{A}}(\mathrm{x}), \mu_{\mathrm{B}}(\mathrm{y})\right)$ 、 （2）ルール構成の決定（「IF〜 THEN $\cdots$ 」構成）、 （3）演算方法（含意公式）の決定 $\left(\mu_{R}(x, y)\right.$ ) , (4) 合成規則の決定 $(\max -\min ) 、 （ 5 ） ル ー ル$ 統合と非ファ ジィ化の方法 $\left(\int \mu_{\mathrm{B}}(\mathrm{y}) / \mathrm{y} \rightarrow \mathrm{y}\right.$ *) の決定である。これら の手順のうち、入力変数が複数の場合には前件部分 の合成方法（"and"の計算）も定義する必要がある。

このとき、上記の手順 $(3)$ 、. (4) と関係する ファジィ概念同士の演算方法には、「Tーノルム」 として与えられる演算を用いることができる。

また通常は、同様な形をした複数のルール群によっ てモデル表現を行うことが多い。これは複数のIF/ THEN型のルールを用いたファジィ推論であるので 「多重ファジィ推論」と呼ばれる。以上のような推 論過程を経て得られる出力（ファジィ数）を当該問 題に対応する実数值に変換する過程が手順（5）の 非ファジィ化であり、この部分の妥当な選択も推論 結果に影響を与えることになる。

\section{2 都市道路網の交通需要推計}

ここでは、ファジィ推論を用いて交通行動を記述 する方法を述べるとともに、都市道路網交通需要推 計の方法に対する応用を述べる。通常、都市高速道 路の交通量予測には「O D 分割・転換率法」が多く 用いられる10)。この方法は、図ー2に示すように、 一般道路利用および高速道路利用それぞれの最短経 路探索を行って、当該 $\mathrm{OD}$ 交通量の分担比率を求め るものである。

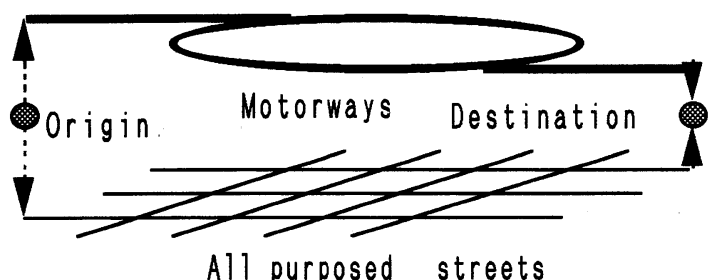

\section{図-2 都市道路網の交通需要推計の概念}

これまで、関数式表現を持つ転換率推計法（転換 率式）には多くのものが提案されている。これらは 実用的な交通量配分におけるサブモデルとして用い られ、いくつかの転換率式が提案されてきた ${ }^{11)} 。 一$ 方言語的表現を利用した定性的な推論モデルを用い
て記述するための研究も提案されファジィ推論によ るモデルの基本構造が示されている。

本研究では従来の成果を踏まえ、より詳細に交通 転換現象を記述するための推論モデル構築を目的と し方法論の比較検討を行う。これはファジィ推論の 応用に対して一般的な示唆を与えるばかりでなく、 現象記述と推論形式の関係が明確となり実用的交通 量配分へ利用する際の留意点が整理される。すでに

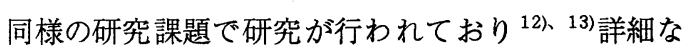
モデル記述方法についてはこれらの研究に譲る。

ここでは、まず実際の配分計算に利用できる形の データを用いて、基本的な転換率推計のためのファ ジィ推論モデルを作成する。つぎに、各方法のその 有効性と実用性を整理し実用的配分法へ導入するた めの考察を行う。

\section{3 ファジィ推論モテルの構成}

ファジィ推論を用いて都市高速道路利用率（転換 率）を推計するためのモデリングについては、いく

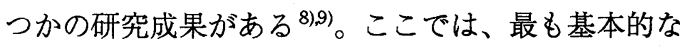
モデル化方法を述べるとともに、同モデルの新たな 展開について述べる。従来の推論モデルでは「時間 差」と「単位距離料金」の二要因を中心として基本 的な推論ルールを作成している。またこのモデルを 説明変数の追加、ルール 構成の変更、演算方法の比 較検討などの点から改良し、現実道路網での交通量 配分問題へ適用し実用性を検討している。これらの 研究から、ファジィ推論モデルは交通選択時の判断 を記述でき交通量配分サブモデルとして利用可能で あるという研究成果が得られている8 。

この点から本研究では、これらの研究成果を参照 してファジィ推論の基本的事項を整理する。また近 年ファジィ推論の実用的な点から提案されている推 論法を検討し、さらにその実用的な利用可能性を検 討する。以下では基本モデルの構成方法について述 べる。これらの手順は、推論過程を持つ現象記述モ デルの一般的作成方法と考えることができる。

\section{(1) 対象地域}

ここでの研究対象は近畿地区の主要道路網である。 具体的には、近畿地区を交通量配分のために121に ゾーン分割し実用的交通量配分に用いられるネット 
ワークを作成したものである。この配分対象の OD ペアは、OD全交通量と都市高速道路転換交通量を

「第17回阪神高速道路起終点調查」と「昭和 60 年 度全国道路交通センサス O D 調查」に基づいて作成 したものである。以下の検討では、ファジィ推論モ デル構造の明確化を目指して、このデータベースよ りランダムサンプル法で57個のODペアを抽出した。

\section{（2）モデル変数と基本構造}

ファジィ推論を行うための説明変数として、「時 間差」と「単位距離料金」を考える。これらは、従 来モデルの構成を踏襲したものであり転換率の関数 的表現を行う際にも多く用いられる変数である。

「時間差」変数は、高速道路所要時間 $\mathrm{t}_{\mathrm{h}}$ 、一般道路 所要時間 $\mathrm{t}_{\mathrm{s}}$ の差である。すなわち、

$x_{1}=t_{s}-t_{h}$

「時間差」は交通経路選択の判断時の基本的変数と 考えられる。したがって、交通利用者の意識面でも 比較的詳細に考慮されていると思われる。与えられ た時間差の值が、利用者の「大」「中」「小」など の言語的変数として何段階に認識するかを理論的に 規定することは難しい。ここでは、既存モデルの中 から最も簡便な場合として図ー 3 に示すような 3 段 階のメンバシップ関数を用いることにした。このメ ンバシップ関数は、それぞれ、PS:Positive Small, PM:Positive Medium,PB: PositiveBigを表している。 図中の $\mathrm{a} \sim \mathrm{f}$ の各点がバラメータとなり形状決定に影 響する。ここでは $\mathrm{a}=0, \mathrm{~b}=\mathrm{c}=\mathrm{d}=15, \mathrm{e}=\mathrm{f}=30$ である。

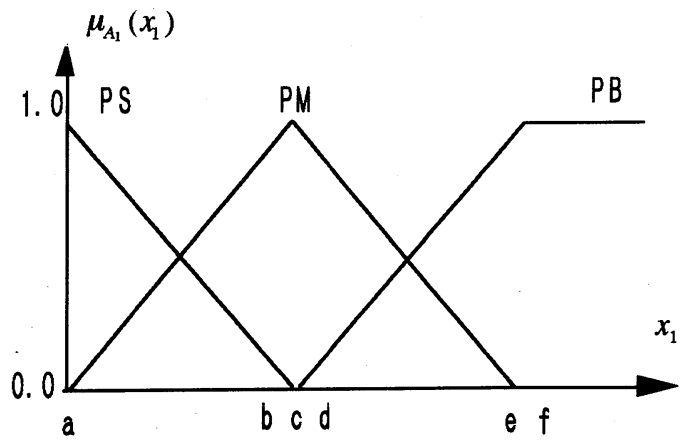

図ー3 時間差変数のメンパシップ関数
「単位距離料金」は高速道路料金を高速道路利用 距離で割ったものである。また州結部に対応する被 説明変数は高速道路利用率 (転換率) である。この 変数は、多段階表現は難しく「大」「中」「小」の 3 種類のメンバシップ関数で表現する。

またメンバシップ関数の形状には、П関数（2次 関数の組合せ）や正規型関数が使われることがある。 一般には形状の簡潔さ、プログラミング効率の良さ から三角型ファジィ数 (Triangular Fuzzy Number: T.F.N.) が用いられる。またファジイ数は、問題に よっては、調査などから推計することができる。同 種の既存研究で「単位距離料金」に対して 3 種のファ ジィ数をファジィデルファイ法 ${ }^{14) を}$ 用いて決定して (る ${ }^{15)}$ 。この算定結果を図ー 4 に示す。

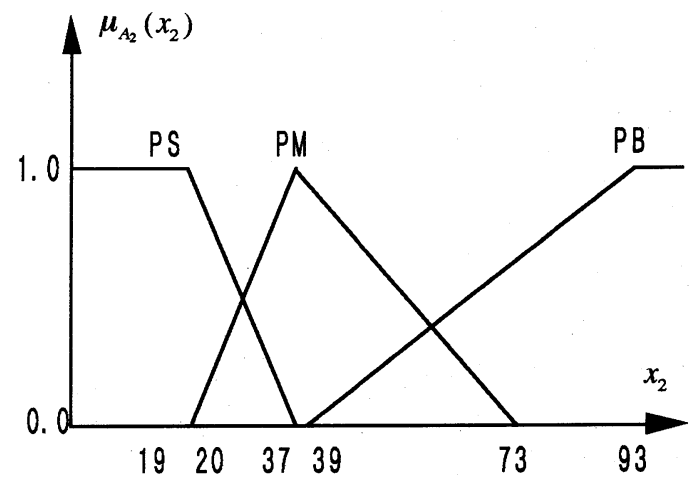

\section{図-4 単位距離料金変数のメンパシップ関数}

さらに「転換率」のメンバシップ関数について検 討した。ルールの後件部に相当する転換率関数は従 来 3 個の標準関数が用いられている。この点も「時 間差」の場合と同様、本来選択がいくつの段階とし て考慮されるかという問題がある。本研究では、交 通選択行動を簡単に記述するためメンバシップ関数 として図 -3 と同様の 3 個の三角型関数を用いる。 このときのパラメータの值は、 $\mathrm{a}=0, \mathrm{~b}=\mathrm{c}=\mathrm{d}=0.5, \mathrm{e}=$ $\mathrm{f}=1.0$ である。

\section{（3）推論ルールの構成とモテル化}

ファジィ推論のルールは、前述のように個々に 「IF/THEN」型ルールで表現できる。通常多重ファ ジィ推論では、多数のルールが同時に設定される。 
本例のように前件部の組合せとしてルール構成が可 能な場合には表一1のように表現することができる。

\section{表-1 ファジィ推論のルール}

\begin{tabular}{|c|ccc|}
\hline$x_{1}$ & P S & PM & P B \\
\hline P S & $M$ & S & S \\
P M & $L$ & $M$ & $S$ \\
P B & $L$ & $L$ & $M$ \\
\hline
\end{tabular}

このルール群の内容は、大局的には「時間差が大 きいとき高速道路利用率が高い」、「単位距離料金 が大きいとき高速道路利用率は小さい」という判断 を記述している。この表中の記号、L、M、S は帰 結部の利用率「大」「中」「小」に対応している。 実際には、いくつかの組合せに対して、推論計算を 実行して推計誤差の小さい組合せを選ふ。誤差指標 に特に決まった形はないが、ここでは、ニューラル ネットワークなどで用いられる誤差

$$
\varepsilon=\sum_{i}\left|R_{i}-P_{i}\right|
$$

を用いている。表一1のルール群の構成はこの誤差 の値を参考にして、数回の試行の結果得られたもの である。すなわち、実績值と推計值の相違と誤差の 発生状況から、問題があると思われる個別ルールの 帰結部を修正していく。本例のように全ルールが少 ない場合には、このような方法の利用が可能である。 このときの誤差の值は $\varepsilon=10.68$ となった。

以上の検討結果から得られたファジィ推論モデル は図一1の手順に対応させて、つぎのように整理で きる。（1）説明変数のメンバシップ関数を時間差 (3 種) 、単位距離料金（3 種）に対して定義し、 また被説明変数の転換率（3 種）のメンバシップ関 数を三角型ファジィ数で表現した。（2）推論ルー ルを前件部の組合せとして最も簡単な $\min$ 演算を用 いる。（3）含意公式として、min演算 $\left(\mu_{R}(x, y)=\right.$ $\left.\mu_{A}(x) \wedge \mu_{B}(y)\right)$ を用いる。(4) 構成演算はMamdani 法にしたがって、max-m in 演算を行う。（5）後件 部の非ファジィ化は一般的なファジィ数の和集合の 重心（max-gravity）で代表させる。すなわち、ここ で得られたファジィ推論モデルは、従来から最も基
本的な形式とされる「Mamdani法」である。この方 法は順次実行される演算形式から「 gravity」型とも呼ばれる5)。またステップ（3）に 「積」演算を用いる方法も従来からファジィ制御な どでよく用いられている方法である。

\section{3. ファジィ推論モテルの諸方法}

\section{1 既存ファジィ推論法の改良}

ファジィ推論モデルの構築方法は、多くの方法が あり各種の検討が行われている。この点について簡 単に研究成果をまとめる。特にファジィ推論の記述 上重要となる各項について順次考察する。

モデル化手順からわかるように推論記述で、最も 重要な点は「ルール構成」である。ファジィ推論は A I 手法で知られるプロダクションシステムの形式 で表現される。したがって基本知識の獲得において は、エキスパートシステム構築と同様な困難さがと もなう。通常、対象問題が複雑であればルール発見 の困難さも大きくなる。現行の多数のファジイ制御 などの応用例では、計測可能な諸変数間の関係を言 語表現でモデル化する場合が多い。その意味では、 ルール構成も簡潔なものが多数見られる。さらに大 規模複雑化したシステムを対象とする場合には、

「ニューラルネットワーク」や「遺伝的アルゴリズ ム」を用いたルール群選択など他手法の援用を考え ることができる。

つぎにファジィ推論の意味として「含意公式」の 形式選定に検討が必要となる。この「含意公式」に

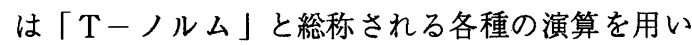
ることができる。この基本的な形は「論理積」、

「代数積」、「限界積」、「激烈積」であり、これ らの選択により推論形式を理論的、実用的に考察で きる。任意の Tーノルム演算値は「論理積」と「激 烈積」の間の值をとることが知られており、4 種類 以外の演算も定義できるが害用的に大差はない。ま た最終的な利用率推計結果を比較すれば、方法間に 有意な推計精度の差異を見いだすことはできない。 したがって、モデル解釈の容易性とファジィ推論の 他過程との融合性（特にmodus-ponensの成立）を考 慮して、「論理積」「代数積」が推奖される ${ }^{9)}$ 。 さらに推論結果とモデル表現值（ここでは、利用 
率の值）の関係を記述する点では「非ファジィ化」 形式の選定も必要である。複数のルール群からなる 「多重ファジィ推論」の帰結である「ファジィ数」 をどのように確定值とするかは、その意味解釈にも 関係する。主要な方法として「重心法」「面積法」 「中央値法」「高さ法」などの方法がある。本例の ような推論結果の分布が複雑化しない場合には、こ れらの方法間の相違は少ない。しかしこれらのうち、 最もよく用いられる「重心法」はその他の方法に比 べて推計精度の変化が大きいことが知られている。

ファジィ推論の記述において、上記の検討事項以 外にメンバシップ関数形状、推論中の「and; かつ」 の算定法などの諸点がある。しかし、いずれも上記 項目に比べると推論結果を大きく変化させる要因で はない。また、モデル化に当たっての実績值の蓄積、 モデルの意味づけなどから具体的な検討することが 重要であると思われる。

さらに人間の認知判断の記述として合理的である とされる方法に「代数積一加算一重心法」がある。 これは従来のマムダニ法とは以下の点が相違する。

(a) 前件部のファジィ数の積演算を「代数積」と する。（すなわち $\left.\mu_{\mathrm{R}}(\mathrm{x}, \mathrm{y})=\mu_{\mathrm{A}}(\mathrm{x}) \mu_{\mathrm{B}}(\mathrm{y})\right)$

（b）ルールを規定する演算（含意公式）を「代数 積」とする。

(c) 確定值への非ファジィ化を「後件部ファジィ 数の分布の和」とする。

「ファジィ推論モデルの手順」に対応させれば、 (2), (3), (5)の部分の変更である。各主要ステップ対 応して「product-sum-gravity」法と呼ばれる。各ステッ プにおける演算の意味は、(a) 前件部の合成では各条 件の適合程度を等ウェイトで考慮する。これにより 条件の適合度合いを総合的に考慮する。(b)演算は全 情報を考虑した代数積を用い後件部と相似形とする。 したがって、結論条件の意味形式が保存される。 (c)統合・非ファジィ化では後件部で得られる全情報 を加算的に利用する。特に帰結部の処理において和 集合 $(\max )$ として処理するより、すべて加算 (sum) することはより合理的推論であるといえる。 また後部件の加算によりファジィ数分布が正規でな くなる (1を越える)ことがある点であるが、非ファ ジィ化で重心值を用いれば大小関係は保存され正規 条件は推論結果に影響がない5),
この「代数積 - 加算一重心法」の実用性の検討 を、転換率值が二定変化をする部分ではマムダニ法 と類似しているが、全体的にゆるやかな変化を持つ

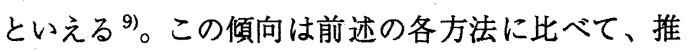
論ルール重複部の関数值が若干大きく評価されるこ とによると考えられる。本例のような転換率推計值 に関して、マムダニ法（「論理積－加算一重心 法」）に比べて、直観に合致した演算であるといえ また適合性も若干向上することがわかった。またこ の方法は「ファジィ制御」においても良好な安定性 が得られるとの報告もある。

\section{2 簡略ファジィ推論}

前項で見たように、ファジィ推論はマムダニ法な どの基本的モデル化ができると、演算方法の組合せ で多くの変化形を考慮することができる。そしてこ れらの各方法からの算出結果から推論モデルとして いずれの方法を採用するかを検討することは容易で ある。しかし、問題によっては推論の表現する意味 内容を深く検討するためというより、通常の推論モ デルに非線形関係を付加することが主目的である場 合も多い。

ここで通常のファジィ推論を演算時間の容易性、 モデル化の簡潔さと計算の高速化を目指して簡略化 した方法がある。これは「簡略ファジィ推論」とよ

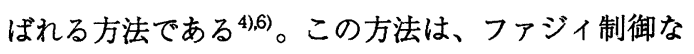
どの推論をより簡単にモデル化するための方法であ る。通常のファジィ推論の手順の内で、㷌結部のファ ジィ数Bがクリスプ数（確定数）としたものである。 制御規則はつぎのように与えられるものとする。

規則 1 : If $x_{1}$ is $A_{11}$ and $x_{2}$ is $A_{12}$ then $y$ is $b_{1}$ 規則 2 : If $x_{1}$ is $A_{21}$ and $x_{2}$ is $A_{22}$ then $y$ is $b_{2}$

規則 $n$ : If $x_{1}$ is $A_{n 1}$ and $x_{2}$ is $A_{n 2}$ then $y$ is $b_{n}$ このとき、つぎのような手順で計算を行う。

a ）各規則の適合度 $w_{i}$ を計算する。

$$
w_{i}=\mu_{A_{i 1}}\left(x_{1}^{*}\right) \times \mu_{A_{i 2}}\left(x_{2}^{*}\right)
$$


b ）推論結果を算出する。

$$
y^{*}=\frac{\sum_{i=1}^{n} w_{i} b_{i}}{\sum_{i=1}^{n} w_{i}}
$$

すなわち、後件部の定数 $b_{i}$ を適合度 $w_{i}$ で荷重平 均したものである。この方法はさきの「product sum-gravity」法の特別な場合に相当している。また

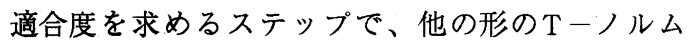
(たとえばmin) を使うことができる。この簡略ファ ジィ推論を用いると重心計算などの非ファジィ化手 順が除かれるので計算は簡単になる。したがって同 種のモデルを作成する際の今後の利用が期待される。

さきの高速道路利用率の推計問題を簡略ファジィ 推論において再度作成した。この場合、結論部をファ ジィ数から通常数とすることになる。帰結部を前モ デルより若干詳細に検討するため、5 種類の值 (very small $=0.0$, small $=0.25$, medium $=0.5$, large $=$ 0.75 , very large $=1.0)$ とした。一方、説明変数の 「時間差」と「単位距離料金」は、さきの通常のファ ジィ推論の場合と同様である。したがって、前件部 分の組合せは同数となりルール数は変化しない。後 件部の種類の変化に対応して、ルール構成を通常方 法にしたがって、試行錯誤的に設定している。この ときのルール構成の与えかたは、前モデルの場合と 同様である。具体的には数回の試行によって、図一 2 に示すルール構成となった。

\section{表-2 簡易ファジィ推論のルール}

\begin{tabular}{|c|ccc|}
\hline$x_{1}$ & P S & PM & P B \\
\hline P S & S & V S & V S \\
PM & L & M & M \\
P B & V L & L & M \\
\hline
\end{tabular}

このときの推計精度は、 $\varepsilon=9.079$ となり、後件部 の分類の増加が前モデルと比べて、若干の推計精度 の向上を与えていることがわかる。

また簡略ファジイ推論と同様の考え方を持つ方法 に関数型推論法がある。この方法では後件部に数値
の代わりに関数を用いるものである。さらに関数推 論法の関数部分をニューラルネットワークで表現す れば、「ファジィ・ニューラルネットワーク」の一 形態と考えることもできる ${ }^{17)}$ 。いずれの場合にも、 ファジィ推論により判断の基本部分を記述するとと もに、推計精度の向上を目指した改良が可能である。

\section{3 遺伝的アルゴリズムの利用}

前項ではファジィ推論モデルの構造面からみた改 良方法を述べた。各種の推論構造を検討することは モデル化の上で重要な要因である。ファジィ推論で は、ルール構成の決定以外にも調整の必要なパラメー 夕が存在する。特に推論に用いるメンバシップ関数 形状を規定する適当なパラメー夕を既存のデータか ら規定する方法が必要とされてきた。

ファジィ推論は全体を非線形の関係を用いて説明 している。すなわち特定の関数形で表現できないた め、微分勾配を考慮した推定方法などを用いること ができない。このため、メンバシップ関数などを試 行錯誤により決定したり、考え得るパラメータのす べての組合せを設定し精度比較によりパラメータ決 定を行ってきた。

近年、このような問題への確率的な探索方法とし て遺伝的アルゴリズム（Genetic Algorithm）の利用

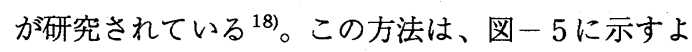
うなアルゴリズムである ${ }^{19)}$

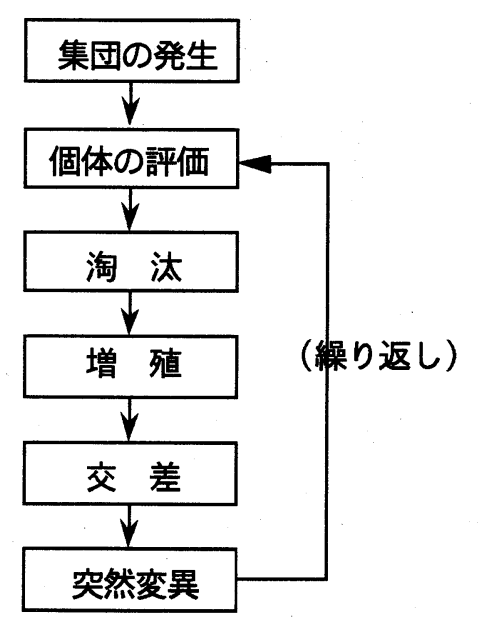

図－5 遺伝的アルゴリスムの基本フロー 
すなわち、対象問題を進化論的に模擬した解釈で、 最適状態を発見する方法である。すなわち、対象問 題は、染色体の組合せとして遺伝子で表現される。 すなわち、 001011100$\}$ （2 進数）あるいは \{256078915\} (10進数) のような形で対象問題 の変数の一状態を表す。初期状態として、特定の個 数の遺伝子（個体）が存在すると考える（集団の発 生）。それらはいずれもシステムの状態を示すこと から、最適化などの指標により個体の適合度が算出 できる（個体の評価）。こうした集団のなかで、進 化論的に適合度の低い個体は自然淘汰される（自然 淘汰）。この個体集団は、残された個体間で交差し、 新しい個体を発生することができるので、集団の個 体数を一定数に保つことができる（交差・増殖）。

このように、親が子を生じるように次世代に相当 する集団が形成されるが、個体中にはこの遺伝操作 とは独立して、ある染色体が突然に別のものになっ てしまうことが起こる（突然変異）。

以上のようなシナリオを模擬的に数字列で表現さ れた遺伝子を用いて繰り返すことで、適合度の大き 嗰体で集団か形成される状態を求めるものである。

ここでは簡略ファジィ推論のルール構成は同一と して、前件部の時間差メンバシップ関数の幅（図一 2 の点の座標）と後件部の值（ $\mathrm{S}$ と $\mathrm{L}$ の設定值） をパラメータと考えた。先に定義した推計誤差をを 最小にする（つまりGAの適合関数を1/ととする）よ うな、パラメータ值の最適な組み合わせを求める問 題となった。ファジィ推論に用いるその他のメンバ シップ関数形もパラメータで表現できるので、具体 的な G A を用いるための方法は、本例以外にも多数 考えることができる20)。

またGAにおいて、計算上検討する必要があるの は、親世代から子世代にいく場合の増殖方法である。 適合関数の逆数を用いて生存率を決定するルーレッ 卜式の選択がよく用いられる。ここでは、簡単に適 合性の高い順に遺伝子を選択し、ランダムに交差す る方法をとった。

さらにGAの計算において設定すべき変数として、 集団数、交差割合、突然変異の割合などがある 19).20;。何回かの試行を行なったが、良好な結果が得 られたのは、集団数 10 , 交差割合 0.3 , 突然変異率 0.2 とした場合であった。
この結果、第 12 世代までの計算で、 $\mathrm{W}_{\mathrm{f}}=27$ 、 $(\mathrm{S}, \mathrm{L})=(0.4,0.6)$ が得られた。ここで $\mathrm{W}_{\mathrm{f}}$ は原点か ら点Cまでの距離である。この場合の誤差は、 $\boldsymbol{\varepsilon}=$ 8.961である。この值は前節の試行錯誤から得られ たファジィ推論モデルの值より小さくなり、GA に よって得られたパラメータがモデル精度を向上させ ていることがわかる。

ここで用いた G A法では、ランダム性が強く残っ ており、限られた演算回数で必ずしも最適解が求め られるとは限らない。しかしながら、その場合でも $\mathrm{W}_{\mathrm{f}}=26 、(\mathrm{~S}, \mathrm{~L})=(0.4,0.6)[\varepsilon=8.987]$ 、あるいは $\mathrm{W}_{\mathrm{f}}=28 、(\mathrm{~S}, \mathrm{~L})=(0.37,0.63) \quad[\varepsilon=8.973]$ などの次 善の解が得られている。塞用的なファジィ推論のパ ラメータとしては、これらの值も利用できることが わかる。以上のように、遺伝的アルゴリズムは、ファ ジィ推論のような非線形関係を持つ場合にも比較的 簡単に応用でき、今後の実用的利用が期待できる。

\section{4. ファジィ数を用いた交通量配分}

情報化が進展し道路網での交通流の現象解析が重 要な課題となっている。前章までに述べたような幹 線道路間あるいは高速道路と一般道路のような道路 網相互の分担モデルとして、ファジィ推論が利用で きることが示された。

道路網の中のさらに詳細な、各リンク交通量を知 るためには、O D間の可能な経路の選択を考虑した いわゆる交通量配分の問題を考える必要がある。こ のようなモデル化では、均衡配分に見られるような 交通配分原則を設定し、それに従うモデルの定式化 と数理計画法による解法を求めるのが一般的である。

近年、確定均衡配分の規定が現実的でないとして、 確率的に交通量を配分するモデルが提案されている。 本研究では、この方向性を参考にして、同㥞にファ ジィ理論によって、交通量配分法を考える場合の諸 点について整理している。

\section{1 認知所要時間の記述}

まずファジイ理論で取り扱う現象を確率理論を利 用した確率均衡配分が扱っている現象と比較するた めに、まず所要時間の認知について考察する。確率 的な交通量配分を考える場合などには、走行調査や 
観測データから知られる実測所要時間に対して利用 者の認知所要時間を考慮している。このとき認知所 要時間は「出発地から目的地までいかほどの時間が 掛かると思うか」という質問に対する回答に相当す ると考えることもできる。

このとき真実所要時間が「30分」であったとする。 多数のドライバーの回答する值は、「31分」「34 分」「28分」などさまざまである。そしてこれらの 值が真実所要時間の回りに分布する。このように考 えると認知所要時間は確率的に求めることができ、 認知所要時間の值は確率分布で表現できる。この手 順が確率的配分の基本的な考え方であり、理論的展 開を行う上の前提として用いられている。道路上で の各ドライバーの経路選択行動を不完全情報による 認知誤差と考えると、このようにモデル化できるこ とになる。

一方、上記の質問に答える各ドライバーの認知内 容を考えよう。「ここから何分かかるか」との質問 の回答に「31分」「28分」などの確定数を用いる ドライバーは果して何割存在するであろうか。また 仮に「28分」という回答が得られても、この数值の 意味は「25分～ 30 分」あるいは「30分ぐらい」で はないだろうか。もちろん毎日の出勤時などにストッ プウォッチを持って継続的に計測しているようなド ライバーは、正確な所要時間と認知所要時間の確率 分布を把握しているかもしれないが、これも極めて まれなことであろう。

また「道路情報」として与えられる「所要時間」 を考えてみよう。この場合、所要時間情報は道路情 報板、路側ラジオ放送などを通じて、対象人物によ らず同一情報であるから、その意味において同様の はずである（確率分布をしない）。しかしながら、 現実には所要時間情報に関する調查結果が示すよう に、すべての人が情報を全く同様に解釈する訳では ない。したがって、現実の「所要時間」は、多数の ドライバー相互に異なるがひとりのドライバーの認 知のなかでもある種の幅を持った数值と考えること ができる。

一個の数值ではなく確率的なひろがりを持つ数を 「ランダム数」また個人の主観的ひろがりを持つ数 を「ファジィ数」とよぶ22)。したがって、上記の説 明は、所要時間のランダム数としての取り扱いとファ
ジィ数としての取り扱いの両方の可能性を示したも のである。これまで見たように両概念は相反するも のではなく、不確実現象に対する視点の相違を示し ている。したがって、この意味では、所要時間は 「ランダム数」であるとともに「ファジィ数」であ ることができる。

\section{2 ハイブリッド数の利用}

ランダム数とファジィ数の両方の性質を持つ数を 「ハイブリット数」という。したがって確率論的な 演算とファジィ理論としての演算を行うことが可能 である。ハイブリッド数は、次式に示すように確率 パラメータ [平均值と分散 (標準偏差)] とファジィ 数パラメータ [メンバシップ関数］を用いて表現さ れる。具体的なハイブリッド数の例は、図一 6 のよ うに描くことができる。

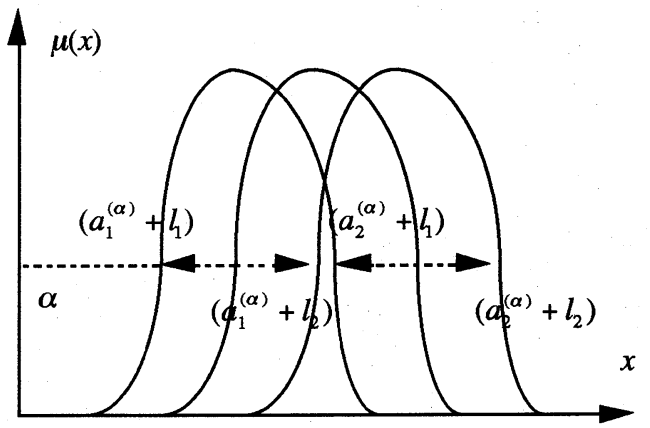

図ー6 ハイブリッド数の概念

このハイブリッド数は、確率部分を正規分布でファ ジィ数部分を三角型ファジィ数で表現したものであ る。道路網上のリンク所要時間がハイブリッド数で あれば、経路所要時間もハイブリッド数で表現でき る。ある確率密度 $f(l)$ を持つランダム数をLとする。 このときファジィ数Aは、確率法則にしたがってラ ンダムに移動する。このような数（A， L)を「ハイ ブリッド数」という。たとえば、 $\mathrm{R}$ 上の 2 つのハイ ブリッド数 $\left(\mathrm{A}_{1}, \mathrm{~L}_{1}\right)$ と $\left(\mathrm{A}_{2}, \mathrm{~L}_{2}\right)$ の和は、つぎのように 計算できる ${ }^{22) 。 ~}$

$$
\begin{aligned}
\left(\mathrm{A}_{1}, \mathrm{~L}_{1}\right)[+]\left(\mathrm{A}_{2}, \mathrm{~L}_{2}\right) & =\left(\mathrm{A}_{1}(+) \mathrm{A}_{2}, \mathrm{~L}_{1}(+)^{\prime} \mathrm{L}_{2}\right) \\
& =(\mathrm{A}, \mathrm{L})
\end{aligned}
$$

この式で、(+)は加法に対する $\max -\min$ 合成を表し、

(+)’は加法に対する確率的合成を示している。ファ 
ジィ数は、ハイブリッド数の 1 つの特別な場合であ り、 $\mathrm{A}=(\mathrm{A}, 0)$ と書ける。ここで 0 は単位分布を持つ ランダム変数である。またランダム数もハイブリッ ド数の特別な場合であり、 $\mathrm{L}=(0, \mathrm{~L})$ である。ここで 0はあいまいさのないファジイ数である。

このようにハイブリッド数では、ファジィ数とラ ンダム数を同時に仮定することができる。つまりファ ジィ数の概念は確率概念と独立して考慮しうるもの である。このとき、各ドライバーの認知する所要時 間は、確率的な認知誤差と持つと同時にファジィ数 としての広がりを持っていることになる。

これまで、交通情報の不完全性を考慮して確率的 側面から交通量配分法の改良が行われてきた。ハイ ブリッド数の定義から、この場合もランダム数はハ イブリッド数の特別な場合であるから、交通量配分 方法のハイブリッド化を行ったものであるといえる。

このようにハイブリッド数とその演算は、従来の 均衡確率配分、確率均衡配分で用いている所要時間 の概念をファジィ数に拡張しても、数学的議論が可 能であることを示している。

\section{3 ファジィ所要時間を用いた交通量配分}

ハイブリッド数のなかで、ランダム性を持たない 場合がファジィ数である。道路交通現象で基本的な ファジィ情報の概念は、ファジィ所要時間として表 現できる。道路網のリンク所要時間がファジィ数で 表現できれば、経路所要時間はりンク所要時間の和 として、同様にファジィ数で表現できる。特に三角 型ファジィ数を考えると、つぎのように経路所要時 間も三角型ファジィ数となる。すなわち 2 つのファ ジィ数 $N\left(p_{1}, q_{1}, r_{1}\right), N\left(p_{2}, q_{2}, r_{2}\right)$ とすると、

$$
\begin{aligned}
& N\left(p_{1}, q_{1}, r_{1}\right)+N\left(p_{2}, q_{2}, r_{2}\right) \\
& \quad=N\left(p_{1}+p_{2}, q_{1}+q_{2}, r_{1}+r_{2}\right)
\end{aligned}
$$

したがって、TFNの両端点および中央点をそれぞ れ加算することで、ファジィ数を算出することがで きる ${ }^{14), 23) 。}$

ここで、交通均衡配分の問題は等価な「数理計画 問題」として定式化できることが知られている 3),11)。リンクの所要時間をファジィ数としても本質 的な交通均衡の概念に相違はないので、この場合の
交通均衡問題は「ファジィ数理計画法」として定式

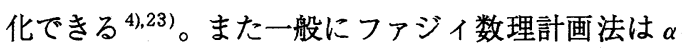
一カット集合の定義（分解定理）を用いて、通常の 数理計画に分解することができる。したがって、 $\alpha$ の変化に従って通常の数理計画問題を解けばファジィ 数としての解集合が得られることになる。これはファ ジィ数を用いて解の存在する可能性分布を表現する ことに相当している。

まず図ー7に示すような道路網を考える。

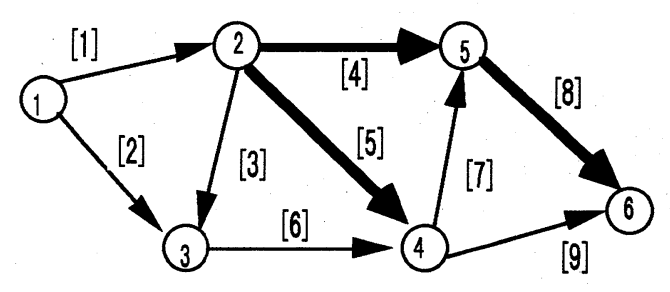

目-7 配分対象道路網

この道路網では、リンク 4、リンク 5 およびリン ク 8 がファジィ所要時間を持ち、その他のリンクは 確定所要時間を持つものとする。つまり確定リンク では通常の均衡配分の仮定と同様、確定リンクは完 全情報が得られているとする。これに対してファジィ リンクは、所要時間に関する情報が十分には提供さ れていない。

各リンクパーフォマンス関数は、B P R 関数（パ ラメー夕は、 $\alpha=0.15 、 \beta=4)$ を用いており、各 リンクの初期所要時間と交通容量はそれぞれ異なる。

ファジィリンク所要時間は図ー 8 に示すようなファ ジィ数で表現される。この中央值 $t_{C}$ はリンクパー フォーマンス関数から得られる通常の（クリスプ） 所要時間に対応している。また $t_{r}$ はファジィ数の 右端（右スプレッド）、 $t_{1}$ は左端（左スプレッド） の值を示している。ここでは、パラメータ $\gamma 、 \beta を$ 用いてつぎのように定める ${ }^{24)}$

$t_{r}=\beta \cdot t_{c}, \quad \beta \geq 1$

$t_{l}=\gamma \cdot t_{c}, \quad 0<\gamma<1$

本例では $\beta=0.7 、 \gamma=1.3$ であり、左右 $30 \%$ のア ジィ性を考慮している。このとき図ー8からわかる 


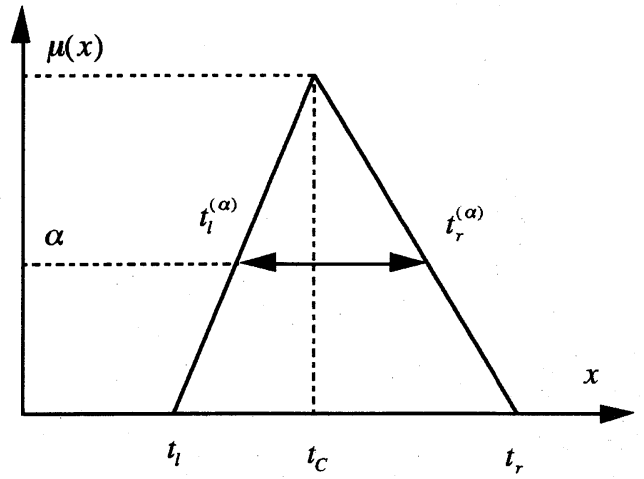

図一８ ファジィリンク所要時間

ように、 $\alpha$ レベル集合を求めるとリンク所要時間は、 $\left[t_{1}{ }^{\alpha} 、 t_{r}{ }^{\alpha}\right]$ の区間数となることがわかる。 さらに計算に用いた $\mathrm{OD}$ 交通量は表一 3 である。

表ー3 配分に用いたOD交通量

\begin{tabular}{|c|c|c|c|c|c|c|}
\hline 1 & 2 & 3 & 4 & 5 & 6 & D $\quad 0$ \\
\hline \multirow[t]{6}{*}{ - } & 100 & 100 & 100 & 100 & 100 & 1 \\
\hline & - & 100 & 100 & 100 & 100 & 2 \\
\hline & & 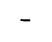 & 100 & 100 & 100 & 3 \\
\hline & & & - & 100 & 100 & 4 \\
\hline & & & & & 100 & 5 \\
\hline & & & & & - & 6 \\
\hline
\end{tabular}

ここで、ファジィ性がない場合 $(\alpha=1 ， 0)$ の 各リンク交通量は、通常の均衡配分計算と等価であ るから FW法を用いて容易に求めることができる。 またファジィリンクを持つ場合には、レベル值 $\alpha$ （>0）が決定されると、計算が実行できる。

ファジィ数に関する四則計算は「拡張原理」を用 いて実行できるが、多くの計算過程を持つ場合には 非常に複雑となり実際的ではない。この場合、実用 的には各ファジィ数の両端点を用いた関数值の組合 せに対応した計算結果から近似する方法用いること ができる。この方法によって各リンク交通量を求め たものが表-- 4 である。

ここでは設定した $\alpha$-レベルからファジィリンク の区間幅が決定され、これに対応して各リンク交通 量が算出されている。各リンク交通量ファジィ性は リンクの特性とネットワーク上の位置関係により異

\section{表-4 交通量配分結果}

\begin{tabular}{cccc}
\hline リンク & $\alpha=1$ & $\alpha=1 / 3$ & $\alpha=0$ \\
\hline 1 & 351 & {$[348,354]$} & {$[347,355]$} \\
2 & 149 & {$[146,152]$} & {$[145,153]$} \\
3 & 101 & {$[100,101]$} & {$[100,100]$} \\
4 & 273 & {$[259,289]$} & {$[256,297]$} \\
5 & 277 & {$[262,290]$} & {$[253,294]$} \\
6 & 350 & {$[346,352]$} & {$[345,353]$} \\
7 & 245 & {$[233,258]$} & {$[227,265]$} \\
8 & 219 & {$[212,230]$} & {$[211,234]$} \\
9 & 281 & {$[270,289]$} & {$[266,289]$} \\
\hline
\end{tabular}

なる。本例ではファジィ情報を仮定したリンク 4 ， リンク 5 , リンク 8 の他に、これらとの隣接リンク でファジィ交通量を観測できる。一方隣接していて

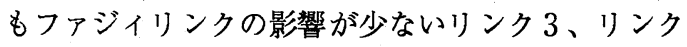
6 が存在する。さらに $\alpha=1 / 3$ と $\alpha=0$ の場合の結 果の比較から、 $\alpha$ の值を減少させるにしたがい、ス プレッドの大きいファジィ交通量が算出されること がわかる。このように、特定のリンクに存在するファ ジィ性を考慮して交通量配分を行えば各リンク交通 量の可能性分布を表現することができる。

\section{5. ファジィ所要時間による経路選択}

\section{1 利用者認知から見たファジィ所要時間}

前述のように「拡張原理」に基づくファジィ数演 算を考える場合、リンク交通量の可能性分布を求め ることができた。しかし所要時間のファジィ性を考 慮して、特定の「均衡状態」を求めるには、ファジィ 経路所要時間を用いて利用者が選択する経路集合を 求める必要がある。

これは所要時間にランダム数を用いて、交通均衡 状態を考えるための確率均衡配分法に対応するもの である。結局、ファジィ経路所要時間の大小比較か ら経路選択モデルを作成することになる。最も簡単 な例は図 -9 に示すような 2 経路問題である。

このような問題では、経験的に利用者が両経路の 所要時間をファジィ数として認識し、経路選択を行 うものと考えている。 


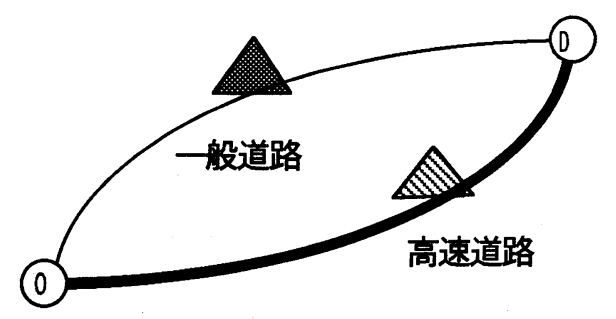

図-9 典型的な 2 経路問題の例

図－10は阪神高速道路の利用者に高速道路・般道路のそれぞれの経路における所要時間情報に対 する認知形状を示したものである。

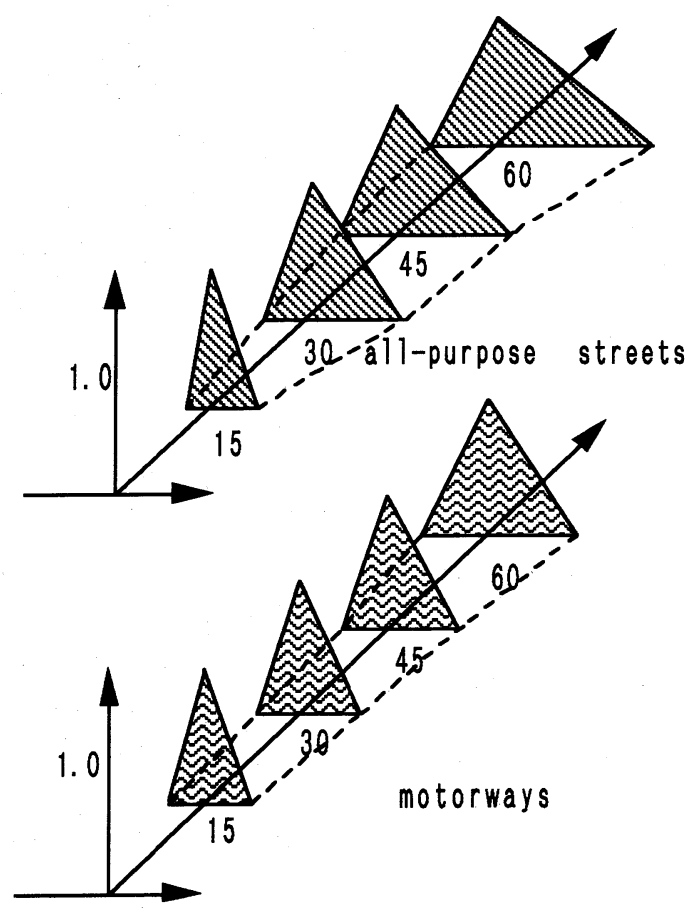

\section{図ー10 利用者によるファジィ所要時間}

本図は15分ごとの所要時間に対して、各回答者の 認知するファジィ数を平均值として表示している。 いずれの経路においても所要時間の中心值が大きく なると認知幅（左右スプレッドの間隔）が大きくな る。また一般道路では、各時間で右スプレッドの大 きい(時間の大きい方に偏った) ファジィ数となっ ている。一方高速道路でのファジィ数は、左右スブ
レッドはほほ等しく、認知幅も一般道路に比べて小 さい。これは、高速道路ではすでに各種の情報提供 が行われ利用者の信頼程度が大きいことに起因する ものと思われる。

したがってファジイ数の比較方法によって、具体 的な計算方法を考える。ファジィ数を大小比較する 方法は、ファジイ数から代表值を得る方法とファジィ 数間の大小程度を表現する指標を求める方法がある。

\section{2 代表值を用いたファジィ数比較}

まず前者の代表值による方法について述べる。こ れには、ファジィ数の「重心位置」や「リムーバル」

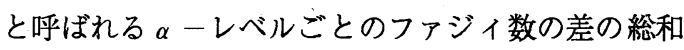
を用いる方法が提案されている。「リムーバル」は ファジイ所要時間相互の総時間差の位置を代表值と する方法である。三角型ファジィ数によって、各リ ンク所要時間を表現すれば、これら代表值は以下の ように算出できる ${ }^{28), 29) 。 ~}$

$$
t_{G}(x)=t(x) \cdot(\gamma+\beta+1) / 3
$$

$$
t_{R}(x)=t(x) \cdot(\gamma+\beta+2) / 4
$$

\section{このような条件下で、交通均衡状態を求めるには、} 三角型のファジィリンク所要時間から拡張原理によ り得られる経路所要時間が三角型ファジィ数である ことを利用する。つまり経路所要時間を示すファジィ 数から比較のための代表値が得られることになる。

したがって、通常数の代わりに得られた代表値を 用いて、FW 法などの配分計算を実行することで交 通均衡の状態を知ることができる。意味論的には、 所要時間のファジィ性（認知幅）を考慮した場合の リンクパフォーマンス関数の修正方法を示している 29)。またファジィリンク所要時間の代表值を用いる ことから、交通量配分結果は、表一 3 のファジィ交 通量の範囲内の一点を算出していることになる。

\section{3 指標值によるファジィ数比較}

つぎにファジィ数の代表值を用いず大小比較を行 う方法について述べる。ファジィ数の大小此較には、 多数の方法が提案されている。主としてファジィ数 同士を直接比較し、ファジィ数の順序関数（相違指 
標）を定義するものである。多くの方法のなかで、 可能性・必然性指標(Possibility/Necessity)による方法 がこの代表的な方法である。2つのファジィ数 $\mathrm{M}, \mathrm{N}$ のメンバシップ関数を、それぞれ $\mu_{\mathrm{M}}(\mathrm{u}), \mu_{\mathrm{N}}$ (v)と表すと、これらはつぎのような定義によって算 出される23),30)。

$$
\begin{aligned}
& \operatorname{Pos}(M \geq N)=\sup _{u \geq v} \min \left(\mu_{M}(u), \mu_{N}(v)\right) \\
& \operatorname{Pos}(M>N)=\sup \inf _{v \geq u} \min \left(\mu_{M}(u), 1-\mu_{N}(v)\right) \\
& \operatorname{Nes}(M \geq N)=\inf _{u} \sup _{v \leq u} \max \left(1-\mu_{M}(u), \mu_{N}(v)\right) \\
& \operatorname{Nes}(M>N)=1-\sup _{u \leq v} \min \left(\mu_{M}(u), \mu_{N}(v)\right)
\end{aligned}
$$

ここで、Pos, Nesは、それぞれ『MがN以上であ る可能性の度合』『Mが $\mathrm{N}$ より大い可能性の度 合』、『Mが $\mathrm{N}$ 以上である必然性の度合』『 $\mathrm{M} か ゙ \mathrm{~N}$ より大きい必然性の度合』である ${ }^{23)}$ 。また、定義式 のうち、 $1-\mu_{M}(u)$ はファジィ集合Mの補集合に対す るメンバシップ関数である。

上記の定義式を参照すると複雑に思われるが、現 実には図-11に示すようにファジィ数のメンバシッ プ関数の各交点の位置によって求められる。この関 係は、一般のファジィ数に対して求めることができ る。しかし三角型ファジィ数を用いれば、いずれの 指標も直線の交点となるので計算は容易となる。

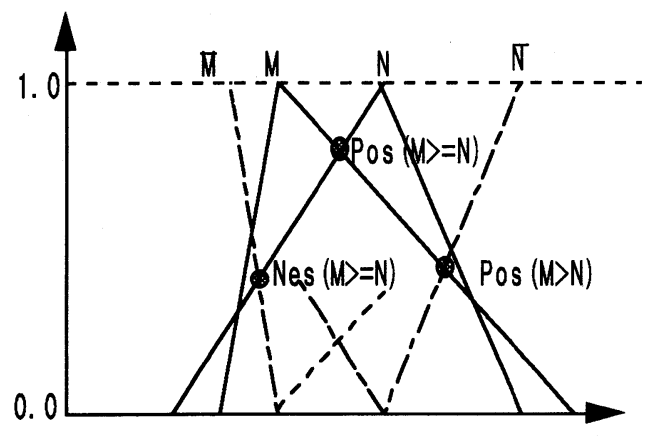

図-11 可能性指標と必然性指標

上記のような 2 経路について、それぞれファジィ 数で所要時間が表現できるとすれば、各指標を計算 することができる。ここでは 2 経路問題として阪神 高速道路と一般道路についての既存データベースを
作成している。図-12 はあるドライバーの認知に よる各ファジィ経路所要時間を示したものである。

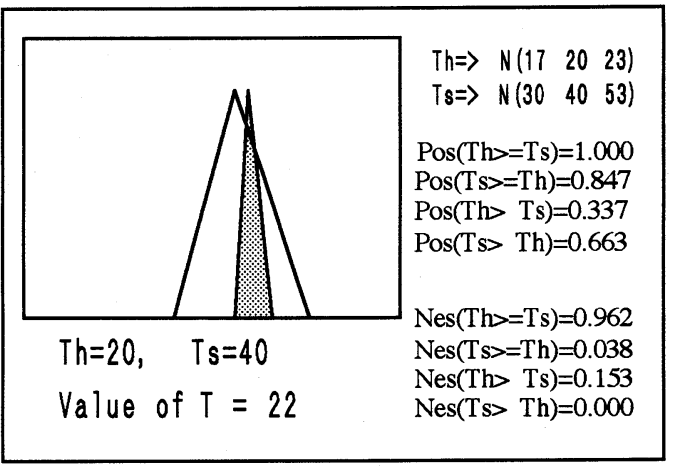

\section{図ー12 特定ドライバーの経路選択状況}

この場合は、具体的なケースとして「高速道路の 所要時間情報が20分で一般道路が40分、さらにこ のドライバー持つ時間評価値が 22 円／分」という場 合を考えている。既存の調查結果からも知られるよ うに、情報化の比較的進んでいる高速道路に関する 所要時間情報を表現したファジイ数は、スプレッド が小さい。

この場合も一般道路所要時間はスプレッドが大き い。また時間表価值から、高速道路の料金抵抗を損 失時間として表現する。本例では、高速道路を利用 することは、 $500 / 22=22.7$ 分（約 23 分）の時間損失 と等価としている。したがって、図中では、高速道 路に対するファジイ数N(17 20 23) にこの值を加え てたN(40 43 46)のT.N.F.が図中に示されている。

またこの場合、2つのファジィ数に関する可能性・ 必然性の指標は合計 8 種類である。本例の場合には、 指標中で明確に（0か 1$)$ 判断されるものは少ないが、 それぞれの值を参照して「一般道路の所要時間がや や小さい」ということがわかる。これらの各指標を 統合的に用いる方法は特にないが、現実の検討には、 このうちいくつかの指標が用いられるべきであろう。

以上のように各所要時間が、ファジィ数である場 合に、これらの大小比較におけるいくつかの基準を 設けることで現実的な表現を行うことができる。現 実には、多数の指標のなかでどの指標を用いるのが 適当か、また判断結果を集約する交通量の推計方法 についての検討が必要である。 


\section{6. おわりに}

本稿では、人間の判断を含む交通現象の解析を行 うためのファジィ理論の適用について、今後の話題 を含めて議論した。土木計画におけるファジィ理論 の応用は、産業界への応用に此べて古くから見るこ とができる。しかしながら、産業界での急速なファ ジィ・ブームは、ファジィを体系化し、さらに応用 的側面を広げることに貢献した1),2),4)。

本稿でも述べ、多くの研究で示されているように ファジィ理論は、各種の応用的局面において既存の 理論と相反する議論をしているものではない。

まず本研究の第一の方法であるファジィ推論は、 エキスパートシステムで用いられる推論を、ファジィ 集合の概念を用いて拡張したものである。土木計画 の多くの問題で、人間の経験や知識を利用した問題 解決が行われているとすれば、今後の応用が期待で きる方法である。

特にファジィ推論法そのものに対しても近年多数 の改良が行われている。含意公式、非ファジィ化な どの推論形式の検討や「多段推論」の利用が問題の 複雑さに応じて利用されることが必要であろう。ま た簡易ファジィ推論や関数型ファジィ推論は、実用 的な推論モデルを作成するためには有効で容易な方 法である。さらに、このようなモデルの簡便化は ニューラルネットワークや遺伝的アルゴリズムなど の方法との結合することで有意義な結果を与える。 特に、メンバシップ関数のパラメータ決定に用いた 遺伝的アルゴリズムは、非線形で不連続的な最適化 を行うという特徵があり、他分野の問題にも適用性 が期待できる。

つぎに述べたファジィ数を応用した交通量配分問 題は、いずれの方法も所要時間情報の持つファジィ 性を表現しようとしたものである。道路網のシステ ム全体が複雑で完全な情報提供が難しい場合の利用 者の認知を表現しようとしたものである。

これまで、確定値と考えたリンク所要時間をラン ダム数と考えるかファジィ数と考兄るかで、交通量 の配分方法が異なる。前者はすでに多数の研究が行 われている確率均衡配分である。ここでは、ファジィ 所要時間を考慮した配分方法を中心的にのべた。し
かしながら、ハイブリッド数の概念を用いれば、こ れらの方法の統合的検討も可能であり、今後は交通 情報と利用者行動との関係を考慮してモデル改良を すすめることができよう。

また後者の分析においては交通情報と交通行動の 分析モデルの作成について検討した。特にファジィ 数の大小比較に関する多くの方法論から有効な行動 規範が得られる可能性が示された。

西洋科学的な数式論理を用いる方法を科学技術を 考えるある種のステレオタイプは依然として多くの 局面で見受けられる。しかしながら従来絶対視され てきた科学的合理性がある限られた閉鎖環境でのみ

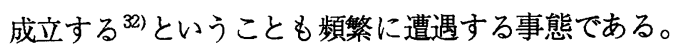

ファジィ理論の対象とする領域は、問題の主観性・ 曖昧性に基づき人間の経験・知識の有効な利用が望 まれる分野である。この意味で、合理主義的な方法 には合致しにくい東洋的発想法に近いものである。 西洋思想と東洋思想あるいは右脳と左脳といった対 比とそれらのバランスを考えると既存方法とファジィ 理論の結合は多くの成果をもたらすと考えられる。

ファジィ理論は近年エキスパートシステム・ ニューラルネットワークなどとの方法論的結合も近 年多く見られ、また欧米にも土木計画分野への応用 の萌芽が見られるようになった ${ }^{33) 35) 。 し か し な か ゙ ら 、 ~}$ わが国ではすでに多くの分野で利用され、世界に先 駆けた研究が進められている。今後土木計画分野に おいてもこれらの成果が先端技術として有効に利用 されることを期待したい。

ファジィ理論の土木計画への応用に関する研究に ついて、招待論文という形で発表の機会を与えてい ただいた土木計画学研究編集小委員会に謝意を表し ます。本稿は同題目（総合題目）での論文奨励賞に 関する論文内容を整理・発展させたものである。

筆者がファジィ理論に関する研究を始めた端緒は 京都大学の佐佐木網教授の御示唆によるものである。 この御卓見に対して染く感謝の意を表します。また 道路網交通解析に関しては京都大学飯田恭敬教授、 交通情報処理に関しては福山大学井上矩之教授に特 に御指導いただいた。さらに本研究の多くの部分は、

(社) システム科学研究所邵春福氏との共同研究で 
ある。そして、多数の研究用資料は阪神高速道路公 団より提供いただいた。ここに記し、これらの方々 に感謝の意を表する次第である。

\section{参考文献}

1) 日本ファジィ学会編：講座ファジィ 5 ファジィ制 御、日刊工業新聞社、1993.

2 ) L.A. Zadeh: Fuzzy Sets and Applications, selected Papers by L.A.Zadeh, 1987. [ザア゙ー・ファジイ理論、日刊工業 新聞社、1992.]

3 ) Sheffi, Y. :Urban Transportation Networks, Prentice-Hall, 1985.

4) 日本ファジィ学会編：講座ファジィ 2 ファジィ集 合、日刊工業新聞社、1993.

5 ) 水本雅晴：わかりやすいファジィ理論IIーファジィ 推論とファジィ制御，コンピュートロール，No.28， pp.32-45, 1989.

6) 古田均・秋山孝正・小尻利治ら：ファジィ理論の土 木工学への応用, 森北出版, 1992.

7 ) 水本雅晴: ファジィ理論入門 ファジィ推論(1), 日 本ファジィ学会誌, Vol.4, No.2, pp.256-264, 1992.

8 ）秋山孝正・邵春福・佐佐木綱：ファジイ理論を用い た転換率推計モデルについての比較研究, 土木計画学 研究・論文集, No.8, pp.185-192, 1990.

9 ) Akiyama, T. , Nakamura, K. and Sasaki, T.: Traffic Diversion Model on Urban Expressway by Fuzzy Reasoning, The Selected Proceedings of the sixth World Conference of Transport Research Vol.II, LYON'92, pp.1011-1022, 1993.

10）土木学会編：交通需要推計ハンドブック，2.5.3.都市 高速道路計画, pp.315-320, 技法堂出版, 1981.

11）土木計画学研究委員会: 第18回土木計画学講習会テ キスト 交通ネットワークの分析と計画一最新の理論 と応用, 土木学会, 1987.

12）佐佐木網・秋山孝正：ファジイ推論と交通行動の記 述, 交通工学, Vol.23, No.3, pp.21-27, 1988.

13）秋山孝正：ファジィ推論を用いるモデル構築手順と その応用的意義について, 土木学会第 45 回年次学術講 演会, 1990.

14) Kaufmann, A. and Gupta, M. M., Fuzzy Mathematical Models in Engineering and Management Science, NorthHolland, 1988. [ 田中英夫監訳、松岡浩訳、ファジィ数 学モデル、オーム社、1992.]

15）秋山孝正・佐佐木網・宇野伸宏・有倉陽司：ファジィ 理論を用いた交通経路選択に関する分析, 第 5 回ファ ジィシステムシンポジウム講演論文集, pp.325-330, 1989.

16）秋山孝正・中村恭子・邵春福：ファジィ推論による 経路選択モデルの推計精度について，第 7 回ファジィ システムシンポジウム講演論文集，pp.519-522, 1991.

17）秋山孝正: 知識利用型の経路選択モデル化手法、土 木計画学研究・論文集、No.11, 1993.
18) Goldberg, D. E. : Genetic Algorithms in Search, Optimization \& Machine Learning, Addison-Wesley, 1989.

19）宮沢丈夫：現代科学の最先端をあなたのパソコンで! 遺伝的アルゴリズムと最適化問題（前），ASCII, Vol.15, \#6, pp.301-306, 1991.

20）山本和美・久保祐二・和多田淳三：遺伝的アルゴリ ズムによるファジィ制御のメンバシップ関数の学習, 第 9 回ファジィシステムシンポジウム講演論文集, pp.97-100, 1993.

21）北野宏明編：遺伝的アルゴリズム, 産業図書, 1993.

22) Kaufmann, A. and Gupta, M. M., Introduction to Fuzzy Arithmetic, Theory and applications, Van Nostrand Reinhold, 1985. [ 田中英夫監訳, 松岡浩訳, ファジイ数理と応用, オーム社,1992.]

23）坂和正敏：ファジィ理論の基礎と応用, 森北出版, 1990.

24）邵春福・秋山孝正・佐佐木綱：ファジィ情報下のネッ トワーク利用者均衡配分の一方法, 交通工学, Vol.25, No.5, pp.13-23, 1990.

25）秋山孝正・片岡孝視・佐佐木網 : 旅行時間情報に関 する利用者意識について, 第 11 回交通工学研究発表会 論文集, pp.133-136, 1991.

26) Akiyama, T. and Yamanishi, H.: Travel Time Information Service Device Based on Fuzzy Sets Theory, Proceedings of the Second International Symposium on Uncertainty Modeling and Analysis, ISUMA'93, pp.238-245, 1993.

27) Campos L. and Verdegay, J. L: Linear Programming Problems and ranking of Fuzzy Numbers, Fuzzy Sets and Systems, Vol.32, No.1, pp.1-11, 1989.

28）邵春福：都市交通管理計画へのファジィ理論の応用 に関する研究, 京都大学学位論文, 1991.

29）秋山孝正・邵春福・佐佐木網：ファジィ経路情報に 基づくネットワーク交通流解析, 土木学会論文集, No.449/IV-7, pp.145-154, 1992.

30) Bortolan, G. and Degani, R.: A Review of Some Methods for Ranking Fuzzy Subsets, Fuzzy Sets and Systems, Vol.15, No.1, pp.1-19, 1985

31) Akiyama, T. and Shao, C.: Motorists Behaviour on the Motorways with Fuzzy Traffic Information, Proceedings of the Fifth IFSA Congress, Vol.1, pp.660-663, 1993.

32）日本ファジィ学会糄：講座ファジィ別巻 1 ファジィ の科学と思想, 日刊工業新聞社, 1993.

33)Tyler, N. : The Design of High Capacity Bus Systems : The Use of Fuzzy Supports to Represent Expert Opinion, The Selected Proceedings of the sixth World Conference of Transport Research Vol.II, LYON'92, pp. 1023-1033, 1993.

34) Nanda, R. and Kikuchi, S.:Estimation of Trip O-D Matrix When Input and Output are Fuzzy, Proceedings of the Second International Symposium on Uncertainty Modeling and Analysis, ISUMA'93, pp.104-111, 1993.

35) Lotan, T. and Koutsopoulos, H. N. : Models for route choice behavior in the presence of information using concepts from fuzzy set theory and approximate reasoning, Transportation, 20, pp.129-155, 1993. 